Kampus 4 Universitas Ahmad Dahlan Jl. Ringroad Selatan, Tamanan, Banguntapan, Bantul

Daerah Istimewa Yogyakarta 55191

Telp. : (0274) 563515 Fax. : (0274) 564604

e-mail : ihtifaz@uad.ac.id

Vol.1, No 1\&2, Juni-Desember 2018, pp. 137-145

ISSN p:2622-4755 e:2622-4798.

DOI: https://doi.org/10.12928/ijiefb.v1i1.248

\title{
Fungsi Intermediary Bank Aceh Setelah Melakukan Konversi Menjadi Bank Umum Syariah
}

\section{Purwanto $^{{ }^{*}}$}

${ }^{1}$ STAI Al-Husain Magelang, Jalan Yogya, Tegal Rejo Lor, Sucen, Salam, Magelang, Jawa Tengah 56484

*e-mail: purwanto@staia-sw.ac.id 
The current issue and full text archive of this journal is available on IHTIFAZ at :

https://doi.org/10.12928/ijiefb.v1i1.248

\section{Fungsi Intermediary Bank Aceh Setelah Melakukan Konversi Menjadi Bank Umum Syariah}

\author{
Purwanto $^{1^{*}}$ \\ ${ }^{1}$ STAI Al-Husain Magelang, Jalan Yogya, Tegal Rejo Lor, Sucen, Salam, \\ Magelang, Jawa Tengah 56484 \\ *e-mail: purwanto@staia-sw.ac.id
}

\begin{abstract}
In 2016-2017 the market share of the Islamic finance industry increased to 5.3\% and 5.78\% even though in 2015 the market share of the Islamic banking industry was only $4.83 \%$. The increase in the market share of the Islamic banking industry, one of which is due to the conversion of Aceh banks into Aceh Syariah banks in 2016. Conversions made by Bank Aceh, in general, have a positive impact on the market share of the Islamic banking industry, but whether there are internal conditions in Aceh Syariah banks themselves significant changes in the Bank of Aceh Syariah in carrying out the intermediary function? To look for this question, this study needs to be done. This study uses quantitative analysis with an approach before after. The research data used are secondary data, namely the data of Aceh Syariah bank financial statements for 18 months before conversion and 18 months after conversion. Data analysis using paired sample t-test using SPSS. 21 software. The results of this study prove that after converting to an Aceh Syariah bank there were significant differences in carrying out the intermediary function both in terms of the amount of funding and the number of deposits. This shows that the change in Aceh's bank brand to Sharia had a positive impact on the people's decision to use the Aceh Syariah bank products.
\end{abstract}

\section{Keywords:}

Islamic Bank, Conversion, Market Share, Brand

\begin{abstract}
Abstrak
Pada tahun 2016-2017 pangsa pasar industri keuangan syariah meningkat menjadi 5,3\% dan 5,78\% padahal pada tahun 2015 pangsa pasar industri perbankan syariah hanya 4,83\%. Meningkatkanya pangsa pasar industri perbankan syariah, salah satunya disebabkan konversi bank Aceh menjadi
\end{abstract}
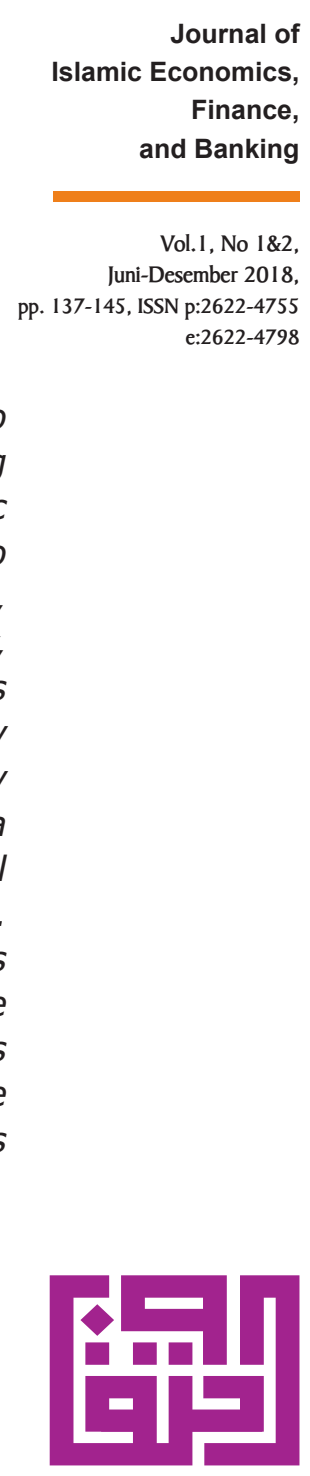

IHTIFAZ

UNIVERSITAS AHMAD DAHLAN

Kampus 4

Universitas Ahmad Dahlan Jl. Ringroad Selatan, Tamanan Banguntapan, Bantul Yogyakarta 55191
mail : ihtifaz@uad.ac.id 
bank Aceh Syariah pada tahun 2016. Konversi yang dilakukan oleh Bank Aceh secara umum berdampak positif terhadap pangsa pasar industri perbankan IHTIFAZ - JIEFB syariah, namun bagaimana kondisi pada internal pada bank Aceh Syariah sendiri apakah ada perubahan signifikan bank Aceh Syariah dalam menjalankan fungsi intermediary? Guna mencari atas pertanyaan ini maka studi ini perlu dilakukan. Studi ini menggunakan analisis kuantitatif dengan pendekatan before after. Data penelitian yang digunakan adalah data skunder yaitu data laporan keuangan bank Aceh Syariah selama 18 bulan sebelum konversi dan 18 bulan setelah konversi. Analisis data menggunakan paired sample t-test dengan menggunakan software SPSS.21. Hasil dari studi ini membuktikan bahwa setelah melakukan konversi menjadi bank Aceh Syariah ada perbedaan yang signifikan dalam menjalankan fungsi intermediary baik dari sisi jumlah pembiayaan dan jumlah DPK. Hal ini menunjukkan bahwa perubahan brand bank Aceh menjadi Syariah berdampak positif dengan keputusan masyatakat untuk menggunakan produk bank Aceh Syariah.

\section{Kata Kunci}

Bank Syariah, Konversi, Pangsa Pasar, Merek

\section{PENDAHULUAN}

Pada tangal 1 September 2016 Bank Aceh resmi melakukan konversi menjadi Bank Umum Syariah. Konversi ini ditetapkan berdasarkan Keputusan Dewan Komisioner OJK Nomor. KEP-44/D.03/2016 tentang pemberian Izin Perubahan Kegiatan Usaha Bank Umum Konvensional Menjadi Bank Umum Syariah terhitung mulai tanggal 1 September 2016. Adanya konversi ini membuat jumlah Bank Umum Syariah di Indonesia pada tahun 2016 menjadi 13 bank (Purba, 2017). Konversi yang dilakukan oleh Bank Aceh menyebabkan peningkatan market share perbankan syariah terhadap pangsa pasar industri kuangan syariah secara nasional. Data dari Otoritas Jasa Keuangan menunjukkan setelah Bank Aceh melakukan konversi market share meningkat tajam menjadi 5,3\% padahal pada tahun 2015 market share perbankan syariah hanya 4,8\%. Pada tahun 2017 market share perbankan syariah meningkat kembali menjadi 5,78\%.

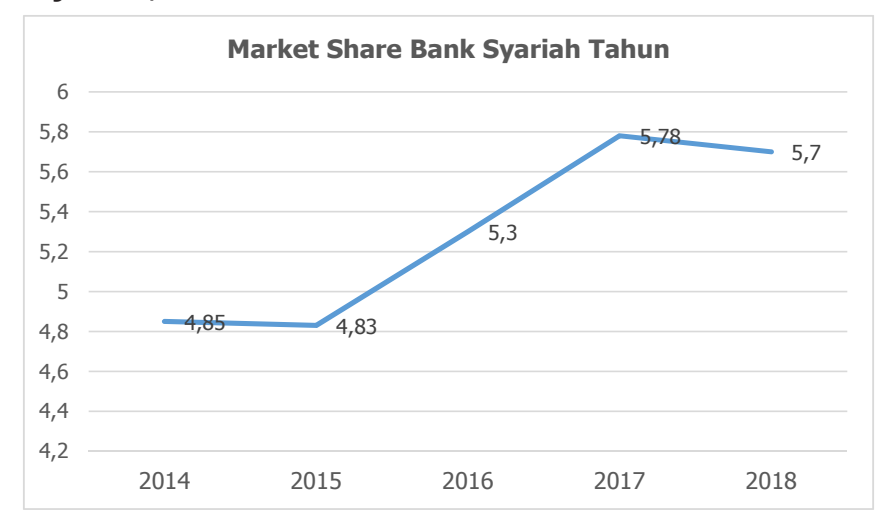

Sumber: diolah kembali dari OJS (2018)

Gambar 1. Pergerakan Market Share Perbankan Syariah Indonesia 
Data di atas menunjukkan bahwa market share perbankan syariah Indonesia mengalami peningkatan setelah adanya konversi yang dilakukan oleh Bank Aceh. Konsekuensi dari pelaksanaan konversi sesuai dengan ketentuan Undang-Undang Republik Indonesia Nomor 21 Tahun 2008 tentang Perbankan Syariah pasal 15 ayat 4 disebutkan bahwa, Bank Syariah yang telah mendapat izin usaha wajib mencantumkan dengan jelas kata "syariah" pada penulisan nama banknya. Artinya p p. 137-145, ISSN p:2622-4755 setelah melakukan konversi, maka nama PT. Bank Aceh harus berubah e:2622-4798 mereknya menjadi PT. Bank Aceh Syariah (Sejarah Singkat, 2018).

Merek merupakan kombinasi dari sebuah nama, tanda, simbol yang digunakan untuk mengidentifikasi barang dan jasa dari sebuah perusahaan sehingga dapat membedakan dengan pesaing dan juga dapat digunakan untuk menciptakan nilai bagi sebuah perusahaan (Hasan, 2014). Salah satu fungsi dari merek bagi konsumen adalah dapat menciptakan keterikatan, sementara baru perusahaan merek dapat bermanfaat untuk menandai kualitas dari produk yang dihasilkan (Kotler dan Keller, 2013). Dengan demikian pemberian nama PT. Bank Aceh Syariah dapat menciptakan daya tarik bagi calon nasabah yang beragama Islam, sementara bagi Bank Aceh Syariah perubahan merek ini dapat menjadi salah satu cara untuk menunjukan kepada masyarakat bahwa mereka menawarkan produk yang sesuai dengan syariah Islam.

Studi yang dilakukan oleh Samidi dkk membuktikan jika ada pengaruh yang signfikan antara merek dengan sikap konsumen terhadap suatu produk (Samidi et al., 2016). Penelitian yang dilakukan oleh Tajudin dan Mulazid juga membuktikan bahwa kesadaran akan merek dapat menentukan keputusan sesorang untuk menggunakan produk perbankan syariah (Tajudin dan Mulzaid, 2017). Hasil penelitian lainya juga membuktikan jika ada pegaruh yang positif antara kesadaran merek dengan keputusan konsumen untuk membeli produk halal (Sunaryo dan Sudiro, 2018).

Dari beberapa penelitian yang telah dilakukan sebelumnya merek merupakan salah satu faktor yang dapat mempengaruhi keputusan masyarakat untuk menggunakan produk bank syariah. Adanya penambahan "Syariah" pada Bank Aceh dapat memberikan informasi kepada masyarakat bahwa Bank Aceh dalam kegiatan orperasionalnya menganut prinsip-prinsip syariah. Adanya perubahan dalam operasionalnya inilah dapat membuat masyarakat tertarik untuk menggunakan produk Bank Aceh syariah baik menyimpan ataupun pembiayaan. Dengan demikian perubahan brand setelah melakukan konversi fungsi intermediary dari Bank Aceh Syariah semakin baik.

Berkaitan dengan brand ada pula penelitian yang membuktikan sebaliknya dimana keputusan masayrakat untuk menggunakan produk bank syariah tidak ditentukan oleh Islamic brand sebagaimana penelitian yang dilakukan oleh Jalil dan Rahaman membuktikan bahwa nasabah memilih bank Syariah bukan karena merek namun karena pelayanan 
yang diberikan (Jalil dan Rahman, 2014). Demikian juga penelitian yang dilakukan oleh Mirza dkk yang membuktikan bahwa keputusan masyarakat untuk menabung dibank syariah tidak ada hubungannya dengan merek (Mirza et al., 2018). Hasil serupa juga dibuktikan oleh penelitian yang dilakukan oleh Yunus dkk juga membuktikan bahwa tidak ada hubungan yang signifikan antara Islamic brand dengan niat untuk menggunakan produk halal (Yunus et al., 2014).

Dari hasil-hasil penelitian yang telah dilakukan sebelumnya belum dihasilkan satu keputusan bulat bahawa Islamic brand dapat mempengaruhi keputusan masyarakat untuk menggunakan produk perbankan syariah. Pada konteks inilah penelitian mengenai fungsi intermediary Bank Aceh setelah melakukan konversi menjadi Bank Umum Syariah. Fungsi intermediary berkaitan dengan kemampuan Bank Aceh Syariah untuk melakukan penghimpunan dana dan menyalurkan dana. Adanya perubahan brand menjadi Bank Aceh Syariah diharapkan dapat menarik minat masyarakat untuk menggunakan produk baik syariah, sehingga fungsi intermediary Bank Aceh Syariah semakin baik apabila dibandingkan sebelum melakukan konversi.

\section{METODE}

Jenis dari studi ini adalah penelitian kuantitatif, dimana analisis data dilakukan berdasarkan angka-angka statistik. Objek dari studi ini adalah laporan keuangan Bank Aceh Syariah baik setelah konversi maupun setelah konversi. Data yang digunakan adalah data selama 18 bulan sebelum Bank Aceh melakukan konversi dan 18 bulan setelah Bank Aceh melakukan konversi. Data penelitian ini adalah data skunder yaitu data yang diperoleh tidak secara langsung oleh peneliti, sehingga peneliti tidak berhadapan langsung dengan sumber data (Purwanto, 2018). Data-data sekunder dalam studi ini diambil secara langsung diperoleh dari www.ojk.go.id.

Fungsi intermediary dalam studi ini terdiri atas kemampuan Bank Aceh Syariah untuk melakukan penghimpunan dana dan penyaluran dana. Sebelum melakukan konversi menjadi Bank Umum Syariah penghimpunan dana diukur dengan jumlah Giro, Tabungan, dan Deposito, sementara untuk penyaluran dana sebelum konversi diukur dengan jumlah kredit yang disalurkan. Adapun setelah melakukan konversi menjadi Bank Umum Syariah penghimpunan dana diukur dengan Dana simpanan wadiah dan dana investasi non profit sharing. Sementara untuk penyaluran dana setelah melakukan konversi diukur dengan jumlah pembiayaan dengan prinsip jual beli, pembiayaan bagi hasil dan pembiayaan dengan prinsip sewa.

Analisis data pada studi ini menggunakan analisis statistik paired sampel $t$ test. Paired sampel $t$ test merupakan pengujian terhadap satu subjek penelitian yang mendapatkan perlakukan berbeda (Wiyono, 2011). Perlakukan berbeda yang dimaksud adalah perlakukan antara 
sebelum dan sesudah Bank Aceh melakukan konversi menjadi Bank Umum Syariah. Dasar keputusan dalam menentukan ada tidaknya perbedaan adalah jika $\mathrm{P}_{\text {value }}$ (Sig) $<0,05$ maka dapat disimpulkan bahwa ada perbedaan fungsi intermediary dari Bank Aceh sebelum dan setelah melakukan konversi.

Uji paired sampel $t$ test merupakan salah satu statistik parametrik sehingga sebelum melakukan analisis harus terlebih dahulu dilakukan uji normalitas terlebih dahulu. Uji normalitas data dilakukan dengan melakukan uji Kolmogorov-Smirnov Test. Sebuah data dapat dikatakan normal jika memiliki nilai asympatic significance > 0.05 (Ghozali, 2018).

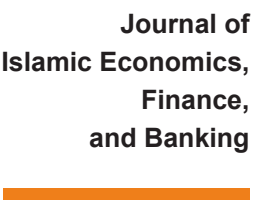

Vol. 1, No 1\&2, Juni-Desember 2018, pp. 137-145, ISSN p:2622-4755 e:2622-4798

\section{HASIL DAN PEMBAHASAN}

\section{Analisis Deskriptif}

Hasil analisis deskiptif ditemukan hasil bahwa secara rata-rata ada peningkatkan jumlah pembiayaan, aset dan dana pihak ketiga setelah Bank Aceh melakukan konversi menjadi Bank Umum Syariah. Data selengkapnya dapat dilihat pada tabel berikut:

Tabel 1. Statistik Deskriptif (dalam Juta)

\begin{tabular}{lrrrc}
\hline Variabel & Minimum & Maximum & \multicolumn{1}{c}{ Mean } & Std. Deviation \\
\hline Pembiayaan & $12,139,871$ & $12,846,692$ & $12,540,551$ & 205,156 \\
Kredit & $9,463,593$ & $10,390,099$ & $9,944,395$ & 260,942 \\
DPK Syariah & $13,825,912$ & $20,705,885$ & $18,131,711$ & $2,138,278$ \\
DPK Konven & $11,072,611$ & $18,188,157$ & $15,014,148$ & $2,040,054$ \\
\hline
\end{tabular}

Sumber: Data di olah dengan SPSS. 21 (2018)

Dari hasil analisis deskriptif di atas dapat diketahui bahwa ada peningkatan baik dari dilihat dari jumlah pembiayaan, aset dan DPK. Sebelum malakukan konversi dalam kurun waktu Januari 2015 hingga Juni 2016 jumlah kredit yang disalurkan oleh Bank Aceh secara rata-rata sebesar Rp 9,944,395 dan jumlah DPK sebesar Rp 15,014,148. Adapun setelah Bank Aceh menjadi Bank Umum Syariah ada peningkatkan dari jumlah pembiayaan dan DPK. Setalah malakukan konversi dalam kurun waktu Januari 2017 hingga Juni 2018 jumlah pembiayaan yang disalurkan oleh Bank Aceh syariah secara rata-rata sebesar Rp $12,540,551$ dan jumlah DPK juga mengalami peningkatkan menjadi sebesar Rp 18,131,711.

Hasil analisis deskriptif di atas menunjukkan bahwa setalah melakukan konversi menjadi Bank Umum Syariah berdampak positif dalam meningkatkan fungsi intermediary dari Bank Aceh Syariah, baik dari sisi penghimpunan dana dan penyauran dana. Peningkatan ini bukan hanya berdampak pada peningkatan jumlah market share bank syariah terhadap jumlah pangsa pasar industri perbankan secara 
nasional, namun juga berdampak positif pada keputusan masyarakat untuk menggunakan produk Bank Aceh syariah.

\section{IHTIFAZ - JIEFB}

\section{Analisis Statistik}

Sebagaimana telah dijelaskan sebelumnya bahwa analisis data pada studi ini menggunakan statistik paired sampel $t$ test. Sebelum melakukan analisis data dengan paired sampel $t$ test maka diperlukan asumsi normalitas data. Setelah dilakukan uji normalitas diperoleh hasil sebagai berikut yang dapat dilihat pada tabel 2 .

Tabel 2. Uji Normalitas Data dengan Kolmogorov-Smirnov Test

\begin{tabular}{llcllc}
\hline & & Pembiayaan & Kredit & DPK Syariah & DPK Konven \\
\hline Normal & Mean & $12,540,551$ & $9,944,395$ & $18,131,711$ & $15,014,148$ \\
Parameters ${ }^{\text {,b }}$ & Std. Dev & 205,156 & 260,942 & $2,138,278$ & $2,040,054$ \\
Most Extreme & Absolute & .163 & .112 & .151 & .110 \\
Differences & Positive & .163 & .104 & .114 & .105 \\
& Negative & -.148 & -.112 & -.151 & -.110 \\
Kolmogorov-Smirnov Z & .692 & .476 & .640 & .468 \\
Asymp. Sig. (2-tailed) & .725 & .977 & .808 & .981 \\
\hline
\end{tabular}

Sumber: Data di olah dengan SPSS. 21 (2018)

Dari hasil uji normalitas di atas dapat disimpulkan bahwa semua data penelitian berdistribusi normal, karena memiliki Asymp. Sig. (2-tailed) > 0,05 . Dengan demikian dapat disimpulkan bahwa analisis data dengan paired sample $t$ test dapat dilakukan karena telah memenuhi asumsi normalitas data.

\section{Analisis Jumlah Pembiayaan yang Dilakukan Bank Aceh Syariah}

Analisis ini dilakukan untuk mengetahu apakah setelah melakukan konversi menjadi Bank Umum Syariah jumlah pembiayaan mengalami peningkatkan jika dibandingkan sebelum melakukan konversi. Dari hasil analisis dengan menggunakan SPSS. 21 diperoleh hasil sebagai berikut yang dapat dilihat pada tabel 3.

Tabel 3. Uji Beda Pembiayaan/Kredit Setelah Konversi

\begin{tabular}{|c|c|c|c|c|c|c|}
\hline \multirow{3}{*}{ Mean } & \multicolumn{4}{|c|}{ Paired Differences } & \multirow[b]{3}{*}{$\mathrm{t}$} & \multirow{3}{*}{$\begin{array}{l}\text { Sig. } \\
\text { (2-tailed) }\end{array}$} \\
\hline & \multirow{2}{*}{$\begin{array}{l}\text { Std. } \\
\text { Deviation }\end{array}$} & \multirow{2}{*}{$\begin{array}{l}\text { Std. Error } \\
\text { Mean }\end{array}$} & \multicolumn{2}{|c|}{$\begin{array}{l}95 \% \text { Confidence Interval of } \\
\text { the Difference }\end{array}$} & & \\
\hline & & & Lower & Upper & & \\
\hline $2,596,155.56$ & $92,494.47$ & $21,801.16$ & $2,550,159.14$ & $2,642,151.97$ & 119.083 & 0.000 \\
\hline
\end{tabular}

Sumber: Data di olah dengan SPSS. 21 (2018)

Hasil analisis paired sampel $t$ test di atas maka dapat disimpulkan bahwa dilihat dari jumlah pembiayaan, ada perbedaan signifikan 
antara sebelum dan sesudah Bank Aceh melakukan konversi menjadi Bank Umum Syariah. Hasil ini diperoleh dari tingkat Sig. (2-tailed) < 0.05, sehingga dapat disimpulkan jika setelah Bank Aceh melakukan konversi menjadi Bank Umum Syariah jumlah pembiyaan yang disalurkan mengalami peningkatan signfikan bila dibandingkan sebelum melakukan konversi.

\section{Analisis Jumlah Dana Pihak Ketiga Setelah Konversi}

Vol.1, No $1 \& 2$, Juni-Desember 2018 , pp. 137-145, ISSN p:2622-4755 e:2622-4798

Analisis ini dilakukan untuk mengetahu apakah setelah melakukan konversi menjadi Bank Umum Syariah jumlah Dana Pihak Ketiga yang berhasil di himpun mengalami peningkatkan ataukah tidak jika dibandingkan sebelum melakukan konversi. Dari hasil analisis dengan menggunakan SPSS. 21 diperoleh hasil sebagai berikut yang dapat dilihat pada tabel 4.

Tabel 4. Uji Beda Dana Pihak Ketiga Setelah Konversi

\begin{tabular}{lllllll}
\hline \multicolumn{2}{ll}{ Paired Differences } & & & & \\
\hline \multirow{2}{*}{$\begin{array}{l}\text { Mean } \\
\text { Std. Deviation }\end{array}$} & $\begin{array}{l}\text { Std. Error } \\
\text { Mean }\end{array}$ & $\begin{array}{l}\text { 95\% Confidence Interval of } \\
\text { the Difference }\end{array}$ & & \\
& & Lower & Upper & t & $\begin{array}{l}\text { Sig. } \\
\text { (2-tailed) }\end{array}$ \\
$3,117,563.06$ & $1,367,577.32$ & $322,341.07$ & $2,437,482.85$ & $3,797,643.26$ & 9,672 & 0.000 \\
\hline
\end{tabular}

Sumber: Data di olah dengan SPSS. 21 (2018)

Hasil analisis paired sampel $t$ test di atas maka dapat disimpulkan bahwa dilihat dari kemampuan menghimpun Dana Pihak Ketiga terdapat perbedaan signifikan antara sebelum dan sesudah Bank Aceh melakukan konversi menjadi Bank Umum Syariah. Hasil ini diperoleh dari Sig. (2-tailed) < 0.05, sehingga dapat disimpulkan setelah Bank Aceh melakukan konversi menjadi Bank Umum Syariah jumlah Dana Pihak Ketiga yang berhasil dihimpun mengalami peningkatan signfikan bila dibandingkan sebelum melakukan konversi.

Hasil analisis baik statistik deskriptif ditemukan hasil bahwa secara rata-rata ada perbedaan dari fungsi intermediary sebelum Bank Aceh melakukan konversi dan setelah melakukan konversi. Jumlah pembiayaan yang dilakukan setelah Bank Aceh melakukan konversi meningkat tajam bila dibandingkan dengan jumlah kredit yang disalurkan sebelum melakukan konversi. Demikian juga halnya dalam penghimpunan dana, ada peningkatan yang siginifikan antara sebelum dan setelah melakukan konversi.

Perbedaan dari fungsi intermediary sebelum Bank Aceh melakukan konversi dan setelah melakukan konversi juga terbukti sangat signifikan. Artinya konsekuensi dari pelaksanaan konversi dari Bank Aceh menjadi Bank Umum Syariah yang harus mencantumkan kata "Syariah" dalam penamaanya mempengaruhi keputusan masyarakat untuk menggunakan 
produk Bank Aceh Syariah. Hasil studi ini mendukung dari hasil-hasil penelitian yang dilakukan oleh Samidi dkk membuktikan jika ada IHTIFAZ - JIEFB pengaruh yang signfikan antara merek dengan sikap konsumen terhadap suatu produk (Samidi et al., 2016). Penelitian yang dilakukan oleh Tajudin dan Mulazid juga membuktikan bahwa kesadaran akan merek dapat menentukan keputusan sesorang untuk menggunakan produk perbankan syariah (Tajudin dan Mulzaid, 2017). Hasil penelitian lainya juga membuktikan jika ada pegaruh yang positif antara kesadaran merek dengan keputusan konsumen untuk membeli produk halal.

Hasil penelitian ini menunjukkan bahwa konversi dari Bank Aceh menjadi Bank Umum Syariah merupakan salah satu faktor yang menentukan masyarakat dalam menggunakan atau tidak menggunakan produk Bank Aceh Syariah. Hal ini dikarenakan konsumen cenderung berinteraksi dengan merek yang mereka sukai dan tertanam dalam pikiran konsumen (Sunaryo dan Sudiro, 2018). Perubahan nama menjadi Bank Aceh Syariah pada akhirnya membuat masyarakat menyadari bahwa Bank Aceh pada saat ini telah melaksanakan bisnisnya sesuai dengan prinsip syariah karena adanya penambanhan kata "Syariah" pada Bank Aceh.

\section{KESIMPULAN}

Hasil analisis dengan menggunakan paired sampel $t$ test diperoleh hasil bahwa konversi yang dilakukan Bank Aceh menjadi Bank Umum Syariah berdampak signifikan terhadap peningkatkan fungsi intermediary Bank Aceh Syariah. Hasil ini menunjukkan bahwa konversi yang dilakukan oleh Bank Aceh dapat menjadi salah satu faktor yang menentukan masayarakat untuk menggunakan produk Bank Aceh Syariah. Hal ini berkaitan dengan adanya kewajiban undang-undang tentang perbankan syariah bahwa setiap bank yang melakukan konversi harus menambahkan kata "Syariah" pada nama banknya, penambahan nama inilah yang pada akhirnya meningkatkan kesadaran merek pada Bank Aceh Syariah.

\section{REFERENSI}

Ghozali, Imam. (2018). Apliksi Analisis Multivariate dengan Program IBM SPSS 25. 9th ed. Semarang: Badan Penerbit Universitas Diponegoro.

Hasan A. (2014). Marketing dan Kasus-Kasus Pilihan. Yogyakarta: CAPS. Jalil, MA dan Rahman, MK. (2014). The impact of Islamic branding on consumer preference towards Islamic banking services: an empirical investigation in Malaysia. Journal of Islamic Banking and Finance. 2(1):209-29.

Kotler, P dan Keller, KL. (2013). Manajemen Pemasaran. 13th ed. Jakarta: Erlangga. 
Mirza, TK; Sudjatno, S; dan Sunaryo, S. (2018) The Role of Customer Value, Islamic Brand Preference, and Image on Deposit Decision. Jurnal Keuangan dan Perbankan. 22(2):350-361.

Purba, AI. (2017). Pengaruh Perubahan Bank Umum Syariah Terhadap Minat Menabung di Bank Aceh Syariah Pada Masyarakat Kabupaten Aceh Tenggara. Jurnal Human Falah. 4(1):72-86.

Purwanto. (2018). Teknik Penyusunan Instrumen Uji Validitas dan

Journal of Islamic Economics, Finance, and Banking

Vol.1, No 1\&2, Juni-Desember 2018, pp. 137-145, ISSN p:2622-4755 e: $2622-4798$ Reliabilitas Penelitian Ekonomi Syariah. Magelang: StaiaPress; 2018.

Samidi, S; Nurfadilah, D; Rivai, A; dan Suharto. (2016). The Impact of Islamic Branding on Consumer'n Attitude Towards Soft Drink Product in Malaysia. Journal of Global Business and Social Entrepreneurship (GBSE). 2(5):66-77.

Sunaryo, S dan Sudiro, SEA. (2018). The Impact of Brand Awareness on Purchase Decision : Mediating Effect of Halal Logo and Religious Beliefs on Halal Food in Malang Indonesia. Australian Journal of Islamic Finance and Business (AJIFB). 4(1):28-37.

Tajudin, MH dan Mulzaid, AS. (2017). Pengaruh Promosi, Kepercayaan Dan Kesadaran Merek Terhdap Keputusan Nasabah Menggunakan Produk Tabungan Haji di Bank Syariah Mandiri KCP. Sawangan Kota Depok. Islamiconomic: Jurnal Ekonomi Islam. 8(1):19-46.

Wiyono G. (2011). Merancang Penelitian Bisnis dengan Alat Analisis SPSS dan SmartPLS.20. Yogyakarta: STIM YKPM.

Yunus, NSNM; Rashid, WEW; Ariffin, NM; dan Rashid, NM. (2014). Muslim's Purchase Intention Towards Non-Muslim's Halal Packaged Food Manufacturer. Procedia - Social and Behavioral Sciences. 130:145-54.

Sejarah singkat [Internet]. Available from: http://www.bankaceh. co.id/?page_id=82 . Di Akses pada 20 September 2018, pukul 15.15 WIB. 